\title{
Reflection of Industrial Structure in Innovative Capability
}

\author{
Pavel Zdrazil, Ivana Kraftova, Zdenek Mateja
}

\author{
University of Pardubice \\ Studentska 95, 53210 Pardubice,Czech Republic \\ E-mail.Pavel.Zdrazil@upce.cz,Ivana.Kraftova@upce.cz,Zdenek.Mateja@upce.cz.
}

cross $^{\text {ref }}$ http://dx.doi.org/10.5755/j01.ee.27.3.13634

\begin{abstract}
One of the declared strategic objectives of the European Union is an increase of applied innovations. The article draws attention to the correlation between innovation capacity and the industrial structure of economies. Its aim is to investigate whether selected groups of European countries show similar trends in industrial structure development reflected in its innovative capacity. For the analysis and evaluation of development in the period 2006-2013, we selected three groups of countries: Benelux, the Visegrad Group and the Baltic Assembly. The innovative capability evaluation, which is represented by the Global Innovation Index, is based partly on an ordinal analysis of its basic indices, but also on the evaluation of gamma-convergence. To assess the evolution of industrial structure, which is divided into five industry groups, the SHA-DE method based on gross added value is applied. The results show the signs of greater dynamics in strengthening innovation when grouping innovation-weaker countries; in terms of the development of disparities in innovative capability, the measured values suggest a divergence of innovatively developed Benelux countries, while in the less developed countries of the Visegrad Group and Baltic Assembly the ranges of disparities are rather stable and tend to weak convergence. In terms of industrial structure, the main differences can be seen among the surveyed groups both in the secondary sector, but particularly in the tertiary "innovative" sector. And it is the results obtained in relation to the share and development of the "innovative" tertiary sector that confirms the assumption that the innovativeness of a country is largely derived not from the entire economy, but mainly from the specific status of a narrow group of industries that can be largely considered the determinants of innovation.
\end{abstract}

Keywords: Innovative Capability, Global Innovation Index, Industrial Structure, SHA-DE Matrix, Benelux, Visegrad Group, Baltic Assembly.

\section{Introduction}

The industrial structures of national, as well as regional, economics are changing rapidly under the impact of innovation, driven by the search for knowledge (Herstad et al., 2014; Malmberg \& Maskell, 2002). The issue is that innovations' effect is asymmetrically distributed across the countries and their economies very greatly (Krugman, 1979). The picture of economic performance in the medium term in response to changes in the industrial structure (changes in the share of industries on the performance, different growth rates of the individual industries), taking into account the level of innovation of a country or region, is an inspiring moment for the assessment of economic development in the liberal tradition, as well as in the environment of higher national or supranational regulation. European countries differ in this respect, but on the other hand, the comprehensive convergence efforts of the EU cohesion policy raises the question of how individual countries or groups of European countries are doing in this respect; how intertwined their innovative capacity and changes in industry structure are; whether a convergence occurs within - in a certain sense "close" - countries. This perspective appears especially significant with respect to the pro-growth objectives set out by the Europe 2020 strategy.

The aim of this paper is to examine whether a group of geographically, culturally and historically close European countries exhibit similar trends in the industrial structure, development, which is reflected in its innovative capacity.

\section{Review of Literature}

Innovations are changing the world and their role in economic growth and wellbeing is generally acknowledged to be true (den Hertog, van der Aa \& de Jong, 2010; Hausman \& Johnston, 2014). In a globally connected world with unknown borders, its bearer is usually the capital with its cross-border mobility. The economic subjects have to reflect that by investing heavily to develop their innovation capabilities (Teece, 2007; Cheng \& Chen, 2013). A certain degree of innovation ubiquity leads to the further unification of the world on one hand, but on the other hand, with a linkage to the Global Paradox (Naisbitt, 1994; Rodrik, 2011; Maskell \& Malmberg, 1999), the pressure on the enforcement of individual and national identity based on ingenuity, creativity and innovativeness increases (Stiglitz, 2015; Keating, 2001). Though innovations tend to be implicitly more associated with the production sector, the considerable impact on consumption is not only mediated by offering innovative goods and services (Hirschman, 1980; Hori et al., 2015), but also deliberately targeted with a direct impact on lifestyle change, as evidenced by the development of mobile information and communications technologies in the last years.

The global importance of innovation and the contribution of individual nations was underlined in this respect in 2007 by Soumistra Dutta and Simon Caulkin by their design of The Global Innovation Index (GII), with the motto "The power of innovation - how nations have responded to the challenges of globalization", which is being determined to this day in 
certain modifications (Dutta \& Caulkin, 2007). All its modifications respect the original idea to evaluate the GII at the input and output. The evaluated pillars include the wealth resources parameters (human resources, capital, investment, infrastructure and technology), but also macroeconomic and business environment which these resources are operating in. The mottos of individual Reports on GII reflect the main development trends. For example, in 2011, the GII Report subtitle showed the manifesting acceleration of growth and development, the engine of which is innovation; for the 2014 GII Report, the basic theme is the human factor in innovation (Dutta, 2011; Dutta, Lanvin \& Wunsch-Vincent, 2014).

According to J. A. Schumpeter, innovations induce dynamic disequilibrium ("waves of creative destruction") as the basis for economic growth and social development, they are generally considered to be a source of competitiveness (Valenta, 2001; Dutta \& Caulkin, 2007; Sabotiene, 2010; Huggins et al., 2014; Peretto, 2015; Steinmetz, 2015). Many studies argue this causation to be relevant largely for competitiveness of national as well as regional economics (Malmberg \& Maskell, 2002; Grant, 1996; Tavassoli \& Carbonara, 2014). J. A. Schumpeter perceives innovation as a cause of cyclical economic developments based on short waves, while his contemporary N. D. Kondratiev perceived cyclical economic developments as linked to structural changes without explicit description of the role of innovation in it in long waves. In the description of the upswing and downswing characteristics of these waves, the importance of diversity of branches (carrier, motive, and induced) and relations between them is emphasized. In additional, Agarwal et al. (2015) points out the Steven Klepper's life cycle patterns of behavior in the industry evolution. Complementary growth of support and drive industries is known as the engine of the economy's movement (Perez, 1983; North, 1994). But the actual impact of technical-technological and economic progress on the processes of globalization and integration is not neglected either, including the impact of market investment behavior to change in the industrial structure of the economy, just like the influence of institutional support for the development of national and regional economies (Kraft \& Kraftova, 2012; Aubakirova, 2014; Jucu, 2015; Drucker, 2015; Ho et al., 2015).

Changes in the sectoral and industrial or branch structure of the economy are the reflection of results regarding the behavior of individual elements and the effect of economic laws when ensuring growth and balance (Kenessey, 1987; Dupont, 2007; Kraftova, Mateja \& Zdrazil, 2013; Corsatea \& Jayet, 2014). For a long time, considerable attention has been given to the dynamically developing tertiary sector (Kellerman, 1985; Borins, 2001). In the worldwide globalized economic space, it is often about the balance between the degree of autocracy and openness of national and regional economies, intensified by the innovative trends.

In preparation for the Europe 2020 strategy, the "Innovation Union" initiative was launched in October 2010, with the declared benefits for employment, green growth and social progress in the EU by 2020 (EC, 2010). The basic strategic framework for individual EU policies known as "smart specialization" is very closely related to it. In accordance with it, the states or EU regions are to develop their innovative strategies to improve their strengths and effectively encourage competitiveness of the region, country, but also all Europe in a globalized world. This newly highlights the emphasis placed on the development priorities in terms of industries and fields (Cadil, 2012). The main strengths are then referred to as domains that can be characterized in terms of economic industries with a significant anchor in the given economy in terms of the labor market and the business and knowledge base (McCann \& Ortega-Argiles, 2015).

The development of domains and their related fields entails economy restructuring, changing the proportion of domains in the created production rather than (non)domains, the dynamics of changes in domains and (non)domains is also different, which is significantly influenced by the implemented innovations. In its manual for the application of smart specialization, the European Commission identifies four basic types of restructuring (EC, 2012): transition (move from one field to another), modernization (technological improvements in the field), diversification (formation of new fields), and the emergence of new domains is considered the highest degree of restructuring.

In addition, P. Cooke (1996) puts the existing "islands of innovation" and "networking paradigm" in the context in terms of regional development. He then attributes characteristic pro-innovation features to the innovation networks, which he summarizes as "4 Is": identification, intelligence, institutions and integration - and understands them as a competitive advantage of the region or country. The policy makers are aware about linkages between innovations and regional development; hence, we could see many regional policies emphasizing innovation networking issue during last years (Caloffi et al., 2015; He et al., 2014). The importance of innovation networking in the neoinstitutional model concept of the "Triple Helix of university-industry-government" is pointed out by Leydesdorff \& Fritsch (2006), who in their research of German and Dutch regions conclude that:

"In many countries innovation policies have focused on the high-tech sector. According to our findings, the mediumtech industry is at least as important for the local quality of the knowledge-based economy.... Knowledge-intensive services can be important for generating employment, but one cannot expect these industries to contribute significantly to the knowledge base of a regional economy." But the importance of high-tech companies in the creation of wealth is seen as positive in various industries and regions (Kraftova, Prasilova \& Mateja, 2011).

The emphasis on the connection between innovation, regional development and competitiveness can be captured in a series of technical considerations. An innovation system is, for example, considered to be an integral part of the technological environment in the "Regional Diamond" model; within the constructed RCI (Regional Competitiveness Index), the highest degree of correlation between RCI, information technologies and telecommunications is recorded within the conditions of production factors (Snieska \& Bruneckiene, 2009). There is also research focused on the creation of a typology of regions, which are to connect the relationship of the economic structure with its innovative potential when assessing competitiveness and development capacity of the (Muller et al., 2006; Ho et al., 2015). 


\section{Research Methods}

We focus our attention on the countries of three European regional groups - Benelux (Belgium - BE, Netherlands - NL, Luxembourg - LU), Visegrad Group (the Czech Republic - CZ, Hungary - HU, Poland - PL, Slovakia - SK) and Baltic Assembly (Estonia - EE, Latvia - LV, Lithuania - LT). In accordance with a defined objective, the research focuses on the assessment of the development of triad groupings, but it also takes into account the existing disparities in the development of individual countries. From the defined sample it is also more than obvious that one of the partial objectives of the research is to assess how the traditional European highly innovative countries of Benelux (BNL) and still relatively recently transformed economics of the Visegrad Group (V4) and the Baltic Assembly (BA) differ in terms of the development of innovation and changes in the industrial structure.

The following methods and assumptions were used to achieve the set goal. The Global Innovation Index (GII) is considered an indicator of innovation. As already partially indicated above, it is a composite indicator evaluating the national economy both in terms of creating conditions and environmental friendliness to innovation (input), but also in terms of outputs, produced by the achieved degree of innovation. The areas of Institutions, Human Capital and Research, Infrastructure, Market Sophistication and Business Sophistication are taken into account within the evaluation of inputs; outputs are then evaluated in terms of the areas of Knowledge and Technology Outputs and Creative Outputs. Overall, the index is composed on the basis of more than 80 unique indicators. For specific parameters, however, it is probably useful to refer to the source publication that examines the methodology of the indicator composition in detail (Dutta, Lanvin \& Wunsch-Vincent, 2014), because in this article we are adopting the indicator in the resulting form as an input for further use, not concerned with its actual structure.

The guarantor of the indicator's relevance is both the academic environment - Cornell University and INSEAD (European Institute of Business Administration) and the application sphere - here represented by the World Intellectual Property Organization (WIPO - a specialized agency of the United Nations). The indicator has been monitored and published since 2007, assessing 143 economies in its latest version (2014). Countries that are included in the final evaluation cover approximately $93 \%$ of the population and more than $98 \%$ of the world's GDP (Dutta, Lanvin \& Wunsch-Vincent, 2014). At the same time, we can say that the lack in the constructed assessment in particular relates to very small and very largely underdeveloped countries. Generally, the overall sample of countries in which the GII indicator is compiled may be seen as sufficient.

The GII indicator is always compiled for the given year based on the previous year - for example, GII 2014 was compiled based on information from 2013, and GII 2007 was compiled based on information relevant to 2006, etc. To maintain the consistency of the evaluated entities or innovation and industrial structure, we will consider the years 2006-2013 to be the monitored period. We will therefore consider that the period's innovativeness $(t)$ is expressed through the GII for the period $(t+1)$.
We monitor the development of innovativeness based on the change of order in the innovativeness of countries (in the ordinal way), which is expressed based on the carrying value of GII. Furthermore, we evaluate the development of disparities in the innovativeness of countries belonging to the groups monitored through $\gamma$-convergence (gammaconvergence). The $\gamma$-convergence method is based on the assessment of changes in the order, principally based on Kendall's concordance coefficient. Specifically, for its expressing we will use a formula that was applied by Boyle $\&$ McCarthy in their study focused on measuring disparities (1999), namely (1)

$$
\gamma=\frac{\operatorname{var}\left(R_{t(i)}\right)+\operatorname{var}\left(R_{t(0)}\right)}{\operatorname{var}\left(R_{t(0)}\right) \cdot 2}
$$

where $\operatorname{var}(R)$ represents the variance in the innovativeness order of the countries, while $t(i)$ indicates the reference years and $t(0)$ represents the base year (in this case 2006).

We monitor innovativeness along with the development of the industrial production structures - expressed by gross value added (GVA); or the development of groups with relatively close industries, and we consider that the national economy can be divided into 21 separate industries based on the statistical classification of economic activities NACE rev. 2 (Eurostat, 2008). The monitoring of individual industries would not be very appropriate for our research, because "a comprehensive review of the trends in industrial structure is possible only with the broad groupings" (Kuznets, 1973). For the purposes of this research, we generally followed the traditional breakdown of economic activities within the three-sector model of the economy, or the division of the economy into primary, secondary and tertiary sectors (Clark, 1957; Fisher, 1939). This fundamental breakdown seems to be a fairly good starting point for the definition of basic industrial groups, or as stated by Kuznets (1973): "the three major industries do differ significantly from each other - in the use of natural resources, in the scale of operation of the productive units common to each, in the production process in which they engage, in the final products that they contribute, and in the trends in their shares in total output and resources used." At the same time, however, we are fully aware of the too general level of breakdown, especially in the tertiary sector, which does not sufficiently reflect fundamental changes in the production structure in the direction of the tangible goods to intangible goods (Shapiro \& Varian, 1999), the different market nature of produced goods, but also the diametrically different importance of innovation for the development of specific sectors. Indeed, the tertiary sector also includes the "knowledge-based industries", for which the high value arising from the proliferation of knowledge and innovation is indeed cardinal compared with the sectors stemming from traditional practices and technologies (Tödtling, Grillitsch \& Höglinger 2012). These knowledgebased industries usually systematically gain importance within the structure of modern economies, because the performance of each region in the globalization era is literally derived from the achieved level of the economy's innovativeness and the ability to transform knowledge into innovation (Malecki, 2010; Tödtling, Asheim \& Boschma, 
2012). The development of these sectors can lead to the direct influence of development also in other sectors of the economy, or indirectly by releasing capacities for further development - these sectors may therefore be labeled the innovation industry drivers, as they are becoming an important driving force for determining the development of the whole economy (Kraftova, Mateja \& Zdrazil, 2013). Furthermore, it is also appropriate to point out that in the context of the tertiary sector, the above knowledge-based industries are not the only ones directed at the production of knowledge and innovation. Generally, the tertiary sector is considered as one of the national economy, which usually occupies a relatively exclusive position in the context of the production and processing of information, knowledge and the resulting innovations (Miozzo \& Miles, 2002).

In its modern form, the tertiary sector seems too general and broad in its entirety for the needs of this research, because in many cases quite insignificantly different industries are included in it - especially in material, technological and knowledge intensity, production process, the final product, but also, for example, in the manner of the functioning of the market with the resulting products and players who enter this market. Given the diversity of the final product we divide the tertiary sector into industries with a predominance of private producers, while transactions with their products are made primarily based on market principles, with a predominance of public sector entities and/or a rather non-market environment. Industries with a predominance of private producers operating based on market principles are further split according to their innovation capability, which is based on the industrial structure of human resources in science and technology. We thus distinguish a group of "traditional" industries - whose share of human resources in science and technology is lower; a group of "innovative" industries - whose share of human resources in science and technology is, vice versa, higher. This classification is made on the basis of aggregated industrial structure of human resources in science and technology for EU28 (28 Countries of the European Union). To define the area of science and technology, we proceed in accordance with the Canberra
Manual (OECD, 1995), data inputs for classification are taken from the Eurostat database (2015). Altogether, we will break down the structure of the national economy into five industry groups - primary sector, secondary sector, and tertiary "traditional" sector, tertiary "innovative" sector and tertiary public/non-market" sector. The specific breakdown of individual sectors in these groups is shown in Table 1. Another possible method of classification is offered by the Fraunhofer-Institute study (Grupp et al., 2000), which provides an overview of the industries with a high proportion of highly qualified employees. However, the outlined overview is based more on the educational attainment factor, rather than the actual or potential contribution to the creation of innovations. Therefore, we believe that the breakdown on the basis of the above outlined key is more appropriate for the classification of the tertiary sector in relation to innovative capability.

As is apparent from Table 1, the primary sector is considered to include the industries of Agriculture, Forestry and Fishing (A) and Mining and Quarrying (B). The secondary sector is regarded to be Manufacturing (C); Electricity, Gas, Steam and Air Conditioning Supply (D); Water Supply (E) and Construction (F). The tertiary "traditional" sector is considered a market sector with a lower number of human resources in science and technology, namely: Transportation and Storage $(\mathrm{H})$; Accommodation and Food Service Activities (I); Real Estate Activities (L) and Administrative and Support Service Activities (N). The tertiary "innovative" sector, by contrast, is considered to contain the industries with a higher proportion of human resources in science and technology Wholesale and Retail Trade; Repair of Motor Vehicles and Motorcycles (G); Information and Communication (J); Financial and Insurance Activities (K) and Professional, Scientific and Technical Activities (M). And the industries in the tertiary "public/non-market" sector include: Public Administration (O); Education (P); Human Health and Social Work Activities (Q); Arts, Entertainment and Recreation (R); Other Service Activities (S); Activities of Households as Employers (T) and Activities of Extraterritorial Organizations and Bodies (U).

Table 1

The classification of the national economy into five industrial groups

\begin{tabular}{|c|c|c|c|c|c|c|c|c|c|c|c|c|c|c|c|c|}
\hline \multirow{2}{*}{$\begin{array}{c}\begin{array}{c}\text { Sector of } \\
\text { the } \\
\text { economy }\end{array} \\
\text { NACE }\end{array}$} & \multirow{2}{*}{$\begin{array}{c}\text { Primary } \\
\mathbf{A}+\mathbf{B}\end{array}$} & \multicolumn{2}{|c|}{ Secondary } & \multicolumn{4}{|c|}{ Tertiary - "traditional" } & \multicolumn{4}{|c|}{ Tertiary - "innovative" } & \multicolumn{5}{|c|}{ Tertiary - "public/non-market" } \\
\hline & & C & $\mathbf{D}+\mathbf{E}+\mathbf{F}$ & $\mathbf{H}$ & I & $\mathbf{L}$ & $\mathbf{N}$ & G & $\mathbf{J}$ & $\mathbf{K}$ & M & $\mathbf{O}+\mathbf{U}$ & $\mathbf{P}$ & $\mathbf{Q}$ & $\mathbf{R}$ & S+T \\
\hline Share $(\%)$ & 0.7 & 11.2 & 4.7 & 2.0 & 0.6 & 1.1 & 1.9 & 7.6 & 6.0 & 4.4 & 10.9 & 10.1 & 16.7 & 17.4 & 2.5 & 2.0 \\
\hline $\begin{array}{c}\text { Total } \\
\text { share }(\%)\end{array}$ & 0.7 & \multicolumn{2}{|c|}{15.9} & \multicolumn{4}{|c|}{5.7} & \multicolumn{4}{|c|}{29.0} & \multicolumn{5}{|c|}{48.7} \\
\hline
\end{tabular}

Notes: Share refer to the average share during 2008-2013 (data on employment in science and technology classified by NACE rev. 2 during 2006-2007 have not been disclosed; however, based on the available period we can say that the shares of the employment in science and technology are relatively stable over time, so we can, probably, assume similar structures during 2006-2007 as well).

To reflect the changes in the industrial structure of GVA, we use the SHA-DE (Share-Development) matrix model, which presents the position of the monitored industrial groups in the context of its contribution to the national economy and the dynamics of trends simultaneously (Kraftova, Mateja \& Zdrazil, 2013). To simplify the interpretation and for clarity, we divide the matrix into 9 sections, and for a considerable differentiation between the observed industrial groups, only parts from this matrix are presented in the analysis. The full matrix of the SHA-DE model is generally shown in Figure 1. 


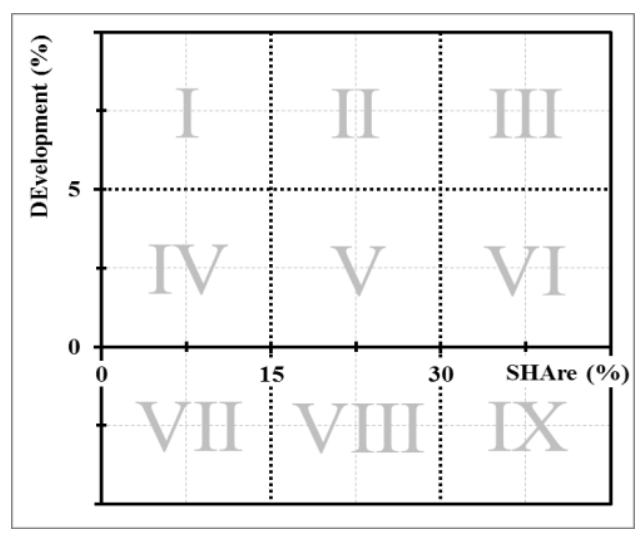

Figure 1. The SHA-DE model matrix

Within the SHA-DE model, we evaluate the proportion of GVA in the observed industrial groups in the state for 2013. The development is expressed by the average annual growth rate, which is measured by geometric mean for the 2006-2013 period - the geometric mean is in fact standardly recognized and recommended as a useful indicator of development and its dynamics (Berenson, Krehbiel \& Levine, 2012). The source database of the GVA's industrial distribution is Eurostat (2015).

\section{Analysis Results}

Before proceeding to the assessment of the development of individual national economy sectors or industries aggregated on the basis of the above outlined key, it seems appropriate to briefly address the development of innovativeness in the monitored countries or groupings, both through the evaluation of the base indices of the innovativeness order for the analyzed groups of countries, and through $\gamma$-convergence evaluations of the innovativeness order within these groupings.

Development of innovativeness in the BNL, V4 and BA countries in the statement emanating from the GII is schematically captured in Figure 2. The development of the monitored grouping is derived based on the average ranking of individual member states; this development is always related to a basic research period, thus to 2006. From Figure 2 it is quite evident that the general trend for all three groups is to strengthen innovation, which is reflected in the declining value of the aggregated order of individual groups. This general trend is then the logical result of mainly growth trends in the innovativeness of individual countries, which is evaluated with a lower rank in terms of index. Furthermore, based on the measured values it can be undoubtedly concluded that in recent years there was practically no decline in the average order of any of the groups. This fact testifies to the stable development of innovation, which is fully in line with developments in other countries (outside the monitored sample), which can be considered relatively close in terms of innovativeness.

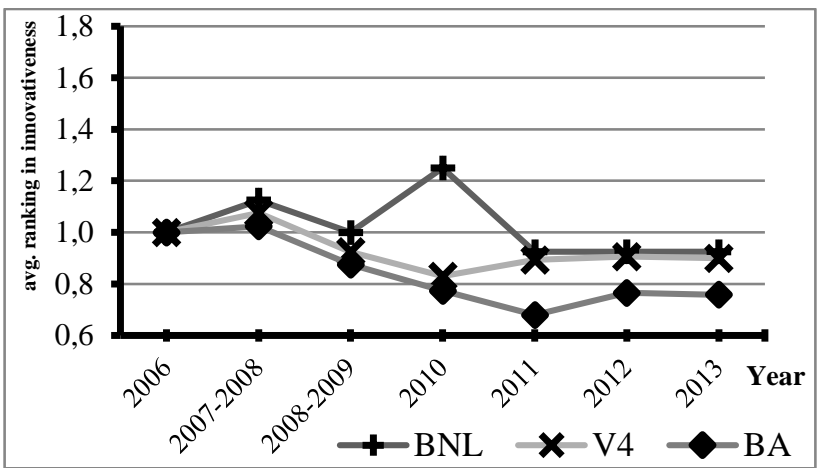

Figure 2. Development of innovativeness of groupings in 2006-2013

Notes: only two-year GII published for the periods 2007-2008 and 20082009; the development of GII is based on the initial year (i.e. 2006).

From a closer examination of the development of innovation it can be stated that in the case of the BNL and V4 groups, there was the comparatively lower strengthening of innovativeness in the monitored period in comparison with the BA group. For this finding, however, the information on the starting positions of the monitored groups and individual countries needs to be supplemented for the objectivity of the assessment - a brief overview of the positions at the beginning of the monitored period is reflected in Table 2 .

Table 2

Ranking of innovativeness in 2006

\begin{tabular}{|ccc|cccc|ccc|}
\hline \multicolumn{3}{|c|}{ BNL } & $\mathbf{1 3 . 3}$ & \multicolumn{4}{|c|}{ V4 } & $\mathbf{3 9 . 8}$ & \multicolumn{3}{|c|}{ BA } & $\mathbf{4 2 . 7}$ \\
\hline BE & NL & LU & CZ & HU & PL & SK & EE & LV & LT \\
\hline 15 & 9 & 16 & 32 & 36 & 56 & 35 & 31 & 50 & 47 \\
\hline
\end{tabular}

After taking into account the starting positions of individual countries, it is evident that the BNL countries have been significantly more innovative since the beginning of the period (2006) than the V4 and BA countries, and after aggregation, the starting positions of this pair can be described as relatively balanced (only with a slightly stronger starting position of the V4 compared to BA). In this context, the development of innovativeness in the BA countries can be described as clearly the most positive, and vice versa, the development of Benelux countries the slowest, though also positive. All these facts are very clearly visible in Figure 2. Nevertheless, given that the level of innovativeness strengthening of the V4 countries in relative terms can be described as almost equal with the BNL countries, it seems appropriate to only identify the V4 countries to be the least positively evolving (in terms of innovativeness). The reason for this conclusion is the significantly different (means better) initial position of the BNL countries, whose potential to further improve their position is logically lower - here we can talk about certain limitations of comparison resulting from the use of the elementary method of ordinal assessment. 


\section{Disparities in innovativeness in the groupings}

Another interesting aspect that can be considered rather complementary in terms of the set problem, but also very interesting, is the issue of disparities in innovativeness of each country grouping. The development of disparities was approached in accordance with the above defined methodology, the development therefore assessed in terms of $\gamma$-convergence. As with the evaluation of simple development, it is absolutely appropriate to highlight the starting position of the monitored countries also in the case of $\gamma$-convergence (see Table 2). All the groups are, in terms of homogeneity, associated with one common feature at the beginning of the monitored period - only one of the countries was significantly deviated in each group (in the case of the BNL it is the positive deviation of NL, in the V4 a negative deviation of PL, and in the BA a positive deviation of EE) while the position of the remaining countries can be regarded as virtually identical. The BNL group can be considered the most homogeneous in the base year (2006), and V4 the least homogeneous; however, the initial disparity between the BA countries is very close to the V4 disparities. Development of disparities in the innovativeness of countries monitored through the $\gamma$ convergence is shown in Figure 3 below.

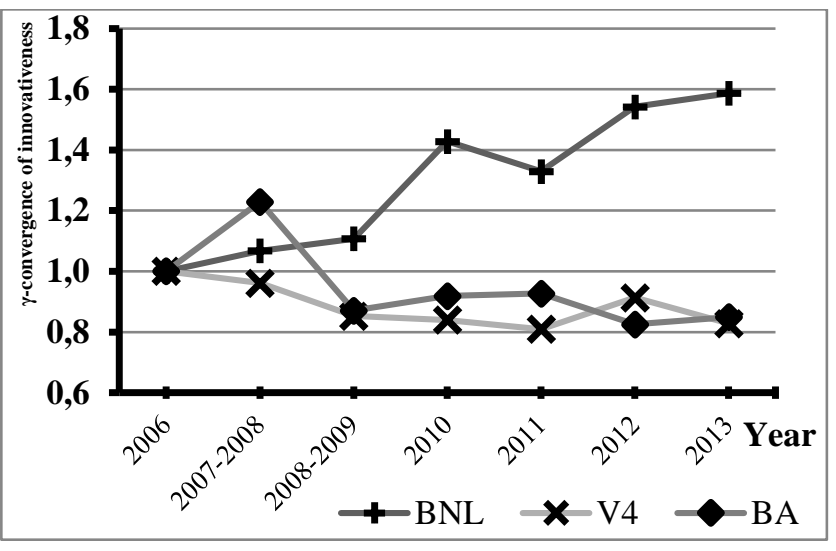

Figure 3. Development of disparities in innovativeness of groupings in 2006-2013

Notes: see notes below Figure 2.

Taking into account the development of disparities shown in Figure 3, it can be stated that the only grouping, whose countries have consistently diverged in the development of innovativeness, is the BNL; the rate of these disparities is actually rather high - during the monitored period there was an increase by about $60 \%$. Conversely, both in the case of the V4 and the BA, there is a noticeable reduction of disparities in the development of innovativeness, and convergence occurs. The reduction of disparities between the interval boundaries of the V4 and BA countries is about $15 \%$, but it can be argued that both groupings have been oscillating around this level since 2008-2009, i.e. for almost all the entire evaluation period. Due to a similar extent of the initial disparities among the V4 and BA countries it is logical that with a comparable development of disparities in both groupings, the range of final disparities in both groups is almost identical.
If we then relate the development of disparities in the innovativeness of the monitored groupings - measured through $\gamma$-convergence - we cannot claim that there is any generally valid relationship between the two phenomena in the monitored groups regarding the development trends in the innovativeness of such groupings. It therefore cannot be said that a higher or lower growth of innovativeness can be automatically associated with convergence or divergence, or differences in their dynamics.

\section{Industrial structures and their changes}

After the passage dealing with the issue of innovativeness within the monitored regional groups in Europe, we now use the SHA-DE model to approach the analysis of industrial structures and their changes. Table 3 shows the shares of the five defined industrial groups in terms of creating GVA in individual national economies in the outer years of the monitored period. It is it clear that the primary sector is generally insignificant and relatively unchanging compared with other industrial groups in the GVA structure. The share of the secondary sector is generally decreasing, the only exception being PL, where its share in the creation of GVA between 2006 and 2013 slightly increased. Interesting differences among regional groupings of countries can be seen in the industrial groups of the tertiary sector. While in all BNL countries there is the identical decline of the "traditional" third sector and a growth in the shares of the "innovative" and "public/non-market" tertiary sector, among V4 and BA countries the shares of the "traditional" tertiary sector increased, with PL again as an exception. The development of the "innovative" and "public/non-market" tertiary sector from the perspective of individual V4 and BA countries is quite individual and cannot be easily generalized.

Table 3

Industrial GVA structure in 2006 and 2013

\begin{tabular}{|l|c|c|c|c|c|c|c|c|c|c|}
\hline & \multicolumn{7}{|c|}{$\mathbf{2 0 0 6}$} & \multicolumn{6}{|c|}{$\mathbf{2 0 1 3}$} \\
\hline Sne. & P & S & TT & TI & TP & P & S & TT & TI & TP \\
\hline BE & 1.1 & 25.1 & 21.0 & 30.5 & 22.3 & 0.9 & 22.4 & 20.1 & 31.7 & 24.9 \\
\hline NL & 5.3 & 21.0 & 19.5 & 32.3 & 22.0 & 5.7 & 18.2 & 17.4 & 33.8 & 25.0 \\
\hline LU & 0.5 & 15.2 & 18.6 & 49.9 & 15.7 & 0.4 & 11.7 & 17.0 & 53.2 & 17.6 \\
\hline CZ & 3.6 & 36.9 & 18.2 & 24.3 & 17.1 & 3.6 & 35.7 & 18.5 & 24.9 & 17.3 \\
\hline HU & 4.3 & 31.1 & 18.3 & 25.6 & 20.8 & 4.6 & 30.0 & 19.9 & 25.4 & 20.1 \\
\hline PL & 5.5 & 30.3 & 14.4 & 32.1 & 17.7 & 5.5 & 31.1 & 14.3 & 32.0 & 17.2 \\
\hline SK & 3.9 & 38.3 & 15.4 & 26.6 & 15.7 & 4.5 & 32.7 & 17.1 & 27.9 & 17.7 \\
\hline EE & 4.0 & 29.7 & 23.2 & 27.7 & 15.3 & 4.9 & 27.6 & 24.3 & 25.8 & 17.4 \\
\hline LV & 4.0 & 23.0 & 25.2 & 29.5 & 18.3 & 4.1 & 22.8 & 27.5 & 27.5 & 18.0 \\
\hline LT & 4.8 & 32.7 & 19.5 & 26.6 & 16.4 & 4.2 & 30.3 & 22.7 & 27.2 & 15.7 \\
\hline
\end{tabular}

Notes: Sne. means sector of the national economy, and therefore $\mathrm{P}$ refers to the primary sector; $\mathrm{S}$ refers to the secondary sector; TT refers to the tertiary "traditional" sector; TI refers to the tertiary "innovativeness" sector and TP refers to the tertiary "public/non-market" sector - all defined as in Table 1 and in the above listed sections.

The next five images (Figure 4-8) represent various parts from the SHA-DE matrices. They were created individually for each of the five industrial groups, always with respect to the deployment of countries into individual matrix sections. In relation to the data presented in Table 3, it should be emphasized that the matrices represent the 
dynamics of sectors "in relation to oneself", but not to the overall development of the economy. Therefore it is no error when, for example, the share of an industrial group declined according to Table 3 between 2006 and 2013, while this industrial group is presented as growing within the below applied SHA-DE model based on the assessment of the average annual growth of the GVA rate.

From Figure 4 it is fairly easy to see that in most monitored countries, the current share of the primary sector on the production value of the national economy is rather minor. With the exception of BE and LU, the primary sector in all the monitored countries contributed to the total value added in a range from 3.6 to $5.7 \%$. In terms of representation of the primary sector, the BNL countries can undoubtedly be described as the most differentiated ones. While the size of the primary sector in NL is the highest of all the monitored countries, LU and BE are in turn associated with the lowest proportions, but also clearly the lowest growth rate in the primary sector - or, in the case of $\mathrm{BE}$, it is even a steady decline.

While there are almost no differences among the V4 and BA countries in terms of the primary sector representation, certain disparities in the development are quite obvious from Figure 4. The annual average growth rate of the primary sector can be identified in the range of about 2.0$5.5 \%$ in most countries of both groupings, and in both groups it is possible to identify one country, whose growth rate is clearly higher compared to others (SK and EE). It can therefore, probably, be concluded that there are differences in the development of the primary sector between the countries in both groupings, but in terms of the entire blocks the differences between the two groups do not appear to be essential.

Figure 5 shows the industrial structure of countries in terms of representation and development of the secondary sector. After the first look at this matrix the differences observed in the distribution of regional groupings can be visually clearly distinguished, and with the exception of $\mathrm{HU}$ we can also simultaneously talk about the relative proximity of countries within each grouping. The lowest shares in the growth rates are shown by the BNL countries as well. LU reaches less than a $15 \%$ share of the secondary sector as the only one of the ten monitored countries in the development of the national economy's GVA, NL with the second lowest share is the only country showing a negative average annual growth rate.

For the BA countries, the shares in the secondary sector range approximately between $23 \%$ and $30 \%$, being very close in terms of development trends - their average annual growth rate will come in a range of one percentage point. The highest representation of the secondary sector in the national economy is linked to the V4 countries, with a summit being its $35.7 \%$ share achieved by the CZ, where the industries have a long and rich tradition (Kraftova, Mateja \& Zdrazil, 2013). PL is again slightly different with the top $6 \%$ average growth rate. Within the regional V4 grouping, an evolutionary divergence of $\mathrm{HU}$ is obvious, whose average annual growth rate is only $0.5 \%$, which is HU partially close to the developed countries of the BNL in this respect.

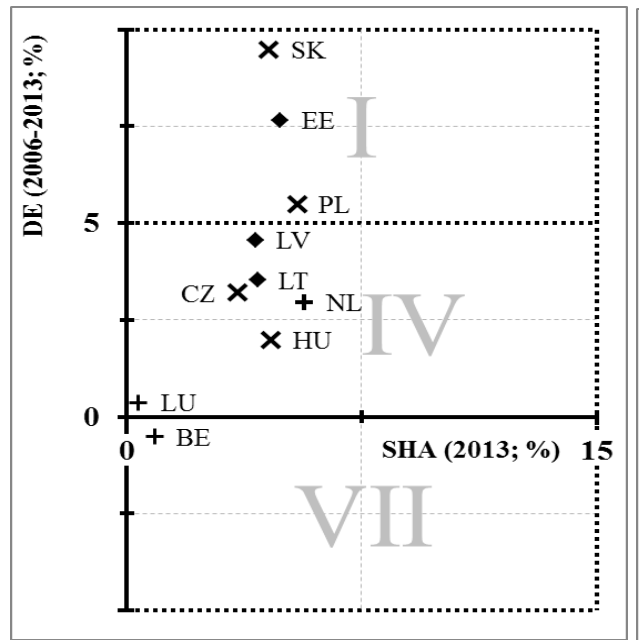

Figure 4. Matrix of the primary sector

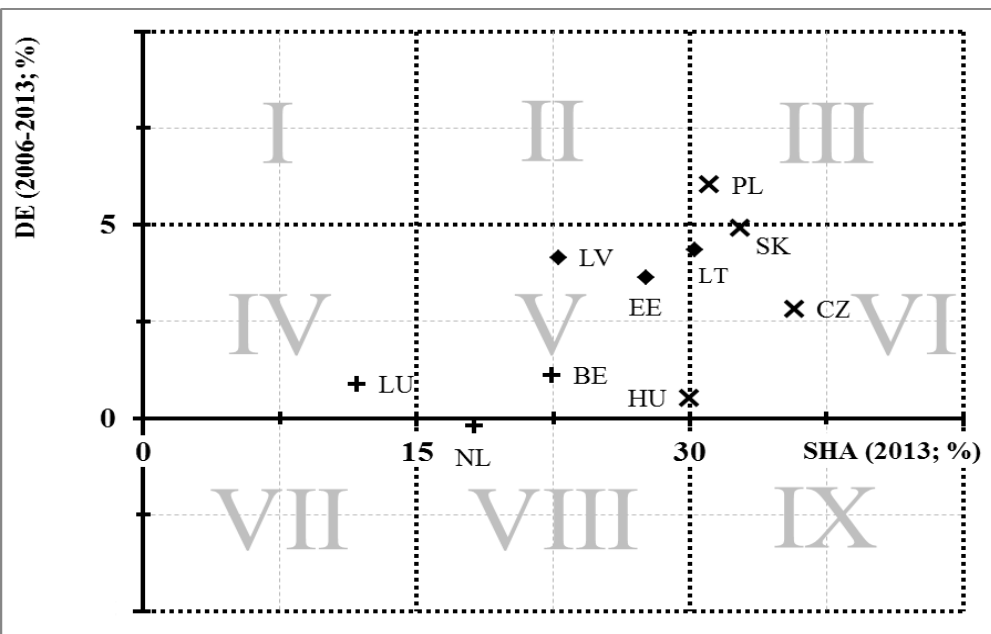

Figure 5. Matrix of the secondary sector

Notes: SHA refers to the share of the sector of economy (or industrial group as we have defined above) in each country in 2013 (based on GVA); DE refers to the development that is expressed by the annual average rate of growth between 2006 and 2013 (based on GVA, estimated as geometric mean); the groups of countries may be distinguished as follow: a cross refers to a Benelux country, an X-shaped cross refers to a Visegrad country, and a diamond refers to a Baltic Assembly country.

A common feature of all three industrial groups defined from the tertiary sector is the fact that the average annual growth rates achieved only positive values in each case, as illustrated by Figures 6, 7 and 8 .

The situation in the industrial group of the "traditional" tertiary sector is documented by Figure 6. From this, we can very well distinguish between the positions of the BNL and BA countries; the BNL countries are found exclusively in Section V of the SHA-DE matrix, the BA countries in
Section II. The BNL grouping is characterized by the lowest margin shares of the "traditional" tertiary sector in the creation of GVA, moving in the range of 17.0-20.1\%. Their growth rates are variable, but all of the values fall within the interval from $0 \%$ to $5 \%$, due to which they can be summed up and distinguished from the other two monitored groups. On the contrary, the higher shares of the "traditional" tertiary sector in the production of the national economy (22.7 to $27.5 \%$ ) and also higher average growth rates are 
typical for the BA countries, for which the common feature is that in all countries they exceed the threshold of $5 \%$.

The characteristic of the "traditional" tertiary sector in the V4 countries seems to be somewhat more complicated, which is caused by the highest differences over participation and development. The lowest proportion of the "traditional" tertiary sector in the creation of GVA is achieved by PL, the only country not exceeding the $15 \%$ threshold, with its 14.3 $\%$ share and a $5.6 \%$ growth rate belonging to the Section I of the SHA-DE matrix (outside the shown sections, hence PL is not captured in Figure 6). The other three countries (CZ, HU, SK) are relatively close in terms of representation of the "traditional" tertiary sector in the national economy (17.1\% to $19.9 \%)$. The great diversity of the V4 countries is mentioned in terms of the development trends evaluated through the annual average growth rate. The lowest growth rate is shown by $\mathrm{HU}$, the highest by SK. The $5 \%$ growth threshold divides the countries into two pairs, $\mathrm{HU}$ and $\mathrm{CZ}$ having less than a $5 \%$ growth rate, PL and SK conversely higher.

Figure 7 shows sections from the SHA-DE matrix created for the tertiary "innovative" sector. These industries are the most developed in the BNL countries, while LU deviates from $\mathrm{BE}$ and $\mathrm{NL}$ in terms of share and development, in both cases in a positive direction. A $53.2 \%$ share of the "innovative" tertiary sector in the creation of LU's GVA is absolutely the highest in this analysis across all five industrial groups.

In the case of the BA countries, we can talk about the similarities of the three countries in terms of the "innovative" tertiary sector's representation in the production of the national economy, their shares ranging between $25.8 \%$ and $27.5 \%$. Developmentally, LT differs from $\mathrm{EE}$ and $\mathrm{LV}$, the average annual growth rate reaching higher values and exceeding the $5 \%$ threshold compared to EE and LV.
From the V4 countries, CZ, HU and SK are relatively similar in terms of the share of the "innovative" tertiary sector $(24.9 \%$ to $27.9 \%)$; PL diverges from them and exceeds the $30 \%$ threshold of the SHA-DE matrix. Following the development trends of the countries, ranking from the lowest growth of $\mathrm{HU}$, through $\mathrm{CZ}$ and PL to the highest growth in the SK, this fully corresponds to the order of these countries within the framework of the growth trends in the "traditional" tertiary sector.

The industrial group of the "public/non-market" tertiary sector is illustrated in Figure 8. It is the only industrial group, in which only two of the nine sections are occupied in the SHA-DE matrix, namely, Sections II and V - it can be obviously stated that in terms of the "public/non-market" tertiary sector, the countries are relatively closest across the monitored sample. BA seems to be the most compact in this sector, which is given by the lowest margin of its shares and the growth rates of the "public/non-market" of the tertiary sector in the production of the national economy. Within the BNL, BE and NL represent a relatively homogeneous pair, whose $24.9 \%$ and $25 \%$ shares of the "public/non-market" tertiary sector are the highest in the sample of countries. LU reaches a lower share, but with a higher growth trend.

From the V4 countries, HU deviates more in this case as well with its share and especially the growth rate of the "public/non-market" tertiary sector. In contrast, the CZ, PL and SK trio is enclosed within a range of just half a percentage point (from $17.2 \%$ to $17.7 \%$ ) in terms of shares. The ranking of countries determined based on the attained growth rate is the same in the "public/non-market" tertiary sector as in the previous two industrial groups. It can therefore probably be deduced that in terms of growth trends, the tertiary sectors of the V4 countries are relatively consolidated, thus with no obvious differences in their development during their segregation and the subsequent evaluation of individual parts.

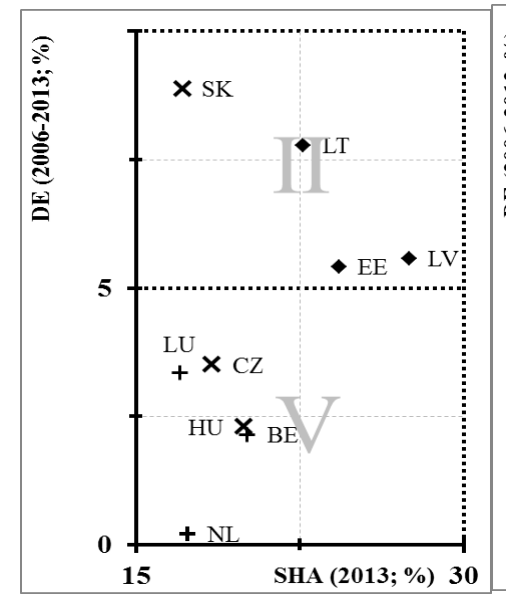

Figure 6. Matrix of the tertiary "traditional" sector

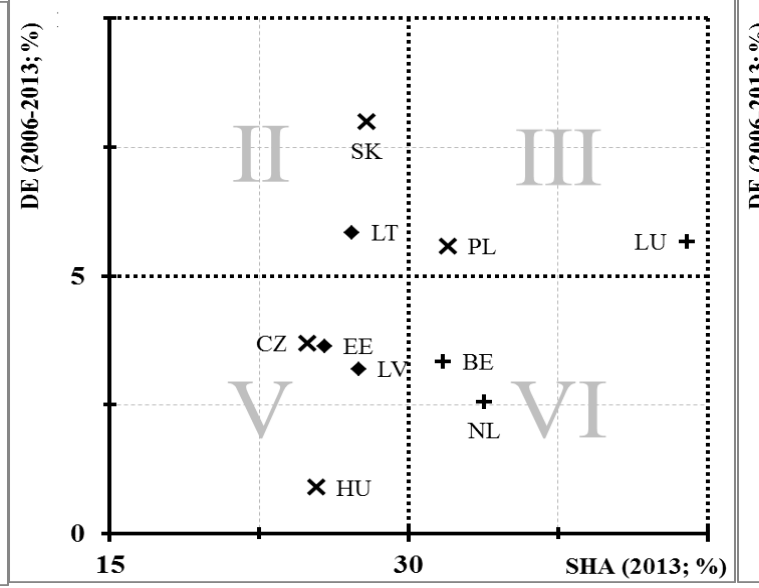

Figure 7. Matrix of the tertiary "innovative" sector

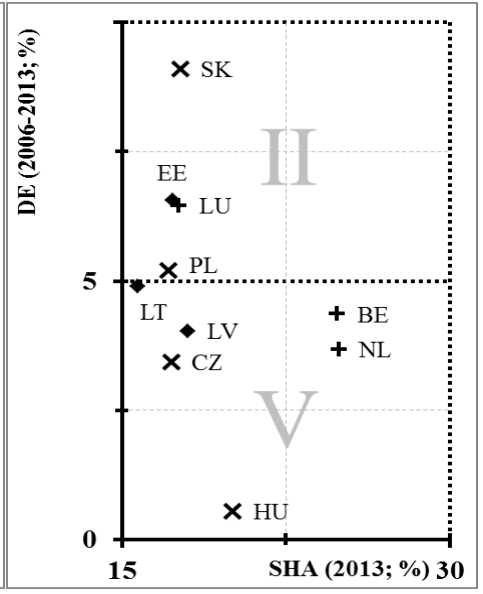

Figure 8. Matrix of the tertiary "public/non-market" sector

Notes: see notes below Figures 4-5

In terms of putting the shares of the monitored industrial groups in the context of their growth trends, it can be stated that a counts of analogies can often be found among the countries within each grouping. These analogies are manifested both in very similar proportions of specific sectors or industrial groups on the composition of the national economy, and also in similar growth trends. These frequent similarities are confirmed by the relative proximity of the countries in the given groupings within the SHA-DE matrices. 


\section{Discussion and Concluding Remarks}

The aim of this paper was to examine whether groups of European countries that are close geographically, culturally and historically exhibit similar trends in the industrial structure, which is reflected in its innovative capacity. Based on our findings, we can conclude the following: The development of innovativeness of the countries in the analyzed groupings can generally be associated with rather very slow, yet slightly strengthening trends, which are a reflection of both the actual potential to produce innovations, as well the ability to actively exploit this potential and continue to develop it. At the same time, the finding that the dynamics of innovation capability is essentially determined by the factual situation that the given country has achieved in the context of innovation, certainly cannot be considered surprising. Thus, in relative terms, the groupings of innovatively weaker countries (Visegrad Group and Baltic Assembly) showed a higher dynamics rate in strengthening innovativeness than in the case of innovatively developed countries (Benelux), though not by too much.

In terms of the development of disparities in innovative capability, the measured values suggest a divergence of the innovatively developed countries of Benelux, while in the less developed countries of the Visegrad Group and Baltic Assembly we can talk about a relatively stable range of disparities, which rather inclines towards weak convergence. By projecting aspect of disparities in the development of innovation groupings Benelux, Visegrad Group and Baltic Assembly, there being no generally valid connections. However, it is to point out the limitations of ranges of the reference sample, making this part of the analysis limited to a certain extent. Generally, so we cannot assume that different growth trends in the context of innovation can be combined with convergence or divergence, or differences in their dynamics. It can be stated that in terms of the development of innovative capability, there is a certain analogy between the groupings of the Visegrad Group countries and the Baltic Assembly, where both groupings differ from Benelux.

In the context of the development of industrial structure within the gross value added of the national economies in the countries of the analyzed groupings, the following trends can be described as dominating: the stable development of the primary sector's share; the declining share of the secondary sector; and thus logically the growing share of the tertiary sector. These findings are completely consistent with the classic theses on the transformation of the national economy structure, which is a direct consequence of its development, or with the second phase of changes in the output structure, which can be characterized by the increasing importance of the tertiary sector at the expense of the secondary sector (Maddison, 1980, Kuznets, 1971). Yet the role of the secondary sector, where the application of innovation undoubtedly plays an important role in ensuring the market competitiveness of its production, it is different among the three groups of monitored countries: Benelux is characterized by the lowest shares and development, the medium values achieved by the Baltic Assembly countries in both parameters, the Visegrad Group is rather destabilized by Hungary, but we can say that in this grouping of countries, the secondary sector has the strongest position, both in terms of its proportion and development.

Development trends within the tertiary sector were monitored based on the sector's segregation into three industrial groups that were determined initially on the basis of the dominant legal status of the entities involved, and the extent of the applied market principles; and consequently for the private market sector they were further classified through the available innovative potential, which was derived from the factor of human resources in science and technology. The subsequent empirical measurements show that there are quite significant differences between the groupings of the Benelux, Visegrad Group and Baltic Assembly countries. While in the Benelux countries there is a uniform decline in the "traditional" tertiary sector and a growth in the proportion of the "innovative" and "public/non-market" tertiary sector, the proportion of the "traditional" tertiary sector is increasing in the countries of the Visegrad Group and the Baltic Assembly, and the development of the "innovative" and "public/non-market" tertiary sector is completely individual from the perspective of each country.

After projecting the general trends of innovation into the development trends of the industries categorized into the "innovative" tertiary sector of the economies in the monitored groupings, it can probably be said that it confirmed the assumption that the innovativeness of economies is largely derived not from the entire economy, but primarily from the specific position of a narrower group of industries, which can be largely considered the determinants of innovation. This assertion can be proven, for example, by the clear deviation of the Benelux countries from the Visegrad Group and Baltic Assembly countries within the "innovative" tertiary sector, which has a significantly higher share on the structure of gross value added. On the other hand, in terms of the growth of the "innovative" tertiary sector, the Benelux countries are not dominant, and in their aggregation it can be said, on the contrary, that the development of the industries categorized into the "innovative" tertiary sector is relatively the slowest in the Benelux grouping - although this fact does not fully correspond to the development of the position of countries in terms of innovativeness in their economies, since in the Benelux countries, the measured positive changes in innovativeness of economies are the lowest.

In conclusion, it must be stated that for the problem addressed by us in the given period and for the primary accentuation of the development of regional groupings - not separate countries - we do not have other relevant studies available, which it would be possible to compare our findings with. Thematically relatively close studies analyzing the development of the development of structure and growth tendencies in the national economy sectors in the context of the European continent (e.g. van Ark, O'Mahoney \& Timer, 2008; Uppenberg \& Strauss, 2010) focus on traditional "western" European countries and approach the tertiary sector's segregation in a different ways. Thus, these studies cannot be used for direct comparison. We can probably conclude that there is a remaining relatively wide scope for subsequent research, whether in terms of the analysis of development trends in the context of regional 
groupings, and the optimization of the segregation of industrial groups, which could be described as relatively "rough" in the context of this paper, and thus partially limiting. Similarly, the identification of relatively significant deviations of specific countries, which was recorded in the monitored sectors, would probably deserve a more detailed analysis, or also the extension of the analysis by other country groupings.

\section{Acknowledgement}

The University of Pardubice, Faculty of Economics and Administration, Project SGSFES_2015001, financially supported this work.

\section{References}

Agarwal, R., Buenstorf, G., Cohen, W.M., \& Malerba, F. (2015). The legacy of Steven Klepper: Industry evolution, entrepreneurship, and geography. Industrial and Corporate Change, 24(4), 739-753. http://dx.doi.org/10.1093/ icc/dtv030

Aubakirova, G. (2014). Features of Innovation Activity management in the Republic of Kazakhstan. Inzinerine EkonomikaEngineering Economics, 25(2), 160-166. http://dx.doi.org/10.5755/j01.ee.25.2.3507

Berenson, M., Levine, D., \& Krehbiel, T. (2012). Basic Business Statistics: Concepts and Applications. New Jersey: Prentice Hall.

Borins, S. (2001). Encouraging innovation in the public sector. Journal of Intellectual Capital, 2(3), 310-319. http://dx.doi.org/10.1108/14691930110400128

Boyle, G., \& McCarthy, T. (1999). Simple Measures of Convergence in per Capita GDP: A Note on Some Further International Evidence. Applied Economics Letters, 6(6), 343-347. http://dx.doi.org/10.1080/135048599353041

Caloffi, A., Rossi, F., \& Russo, M. (2015). What Makes SMEs more Likely to Collaborate? Analysing the Role of Regional Innovation Policy. European Planning Studies, 23(7), 1245-1264. http://dx.doi.org/10.1080/09654313. 2014.919250

Cheng, C., \& Chen, J. (2013). Breakthrough innovation: the roles of dynamic innovation capabilities and open innovation activities. Journal of Business \& Industrial Marketing, (28(5), 444-454. http://dx.doi.org/10.1108/088586 21311330281

Clark, C. (1957). Conditions of Economic Progress. London: MacMillan.

Cooke, P. (1996). The New Wave of Regional Innovation Networks: Analysis, Characteristics and Strategy. Small Business Economics, 8(2), 159-171. http://dx.doi.org/10.1007/BF00394424

Corsatea, T., \& Jayet, H. (2014). Spatial patterns of innovation activities in France: market's role versus public research efforts. Annals of Regional Science, 52(3), 739-762. http://dx.doi.org/10.1007/s00168-014-0608-2

Cadil, V. (2012). Smart specialisation as a new concept of the EU regional innovation policy. Ergo, 7(3), 16-20. http://dx.doi.org/10.2478/v10217-012-0010-2

Den Hertog, P., van der Aa, W., \& de Jong, M. (2010). Capabilities for managing service innovation: towards a conceptual framework. Journal of Service Management, 21(4), 490-514. http://dx.doi.org/10.1108/09564231011066123

Drucker, J. (2015). An Evaluation of Competitive Industrial Structure and Regional Manufacturing Employment Change. Regional Studies, 49(9), 1481-1496. http://dx.doi.org/10.1080/00343404.2013.837874

Dupont, V. (2007). Do geographical agglomeration, growth and equity conflict? Papers in Regional Science, 86(2), 193213. http://dx.doi.org/10.1111/j.1435-5957.2007.00118.x

Dutta, S., \& Caulkin, S. (2007). The Power of Innovation. The World's Top Innovators. Available from internet: https://www.globalinnovationindex.org/userfiles/file/gii-2007-report.pdf

Dutta, S. (2011). The Global Innovation Index 2011. Accelerating Growth and Development. Available from internet: http://www.globalinnovationindex.org/userfiles/file/gii-2011_report.pdf

Dutta, S., Lanvin, B., \& Wunsch-Vincent, S. (2014). The Global Innovation Index 2014: The Human Factor in Innovation. Geneva: WIPO. Available from internet: https://www.globalinnovationindex.org/userfiles/file/reportpdf/GII-2014v5.pdf

EC. (2010). Europe 2020 Flagship Initiative Innovation Union. $\operatorname{COM(2010)} 546$. Available from internet: https://ec.europa.eu/research/innovation-union/pdf/innovation-union-communication_en.pdf

EC. (2012). Guide to Research and Innovation Strategies for Smart Specialization (RIS 3). Available from internet: http://ec.europa.eu/regional_policy/en/information/publications/guides/2012/guide-to-research-and-innovationstrategies-for-smart-specialisation

Eurostat. (2015). Database. Available from internet: http://ec.europa.eu/eurostat/data/database

Eurostat. (2008). NACE rev. 2 - Statistical classification of economic activities in the European Community. Luxembourg: Office for Official Publications of the European Communities. 
Fisher, A. (1939). Production, primary, secondary and tertiary. Economic Record, 15(1), 24-38. http://dx.doi.org/10.1111/ j. 1475-4932.1939.tb01015.x

Grant, R. (1996). Prospering in dynamically-competitive environments: Organizational capability as knowledge integration. Organization Science, 7(4), 375-387. http://dx.doi.org/10.1287/orsc.7.4.375

Grupp, H., Jungmittag, A., Schmoch, U., \& Legler, H. (2000). Hochtechnologie 2000. Karlsruhe: Frauenhofer-Institut.

Hausman, A., \& Johnston, W. (2014). The role of innovation in driving the economy: Lessons from the global financial crisis. Journal of Business Research, 67(1), 2720-2726. http://dx.doi.org/10.1016/j.jbusres.2013.03.021

He, S., Macneill, S., \& Wang, J. (2014). Assessing Overall Network Structure in Regional Innovation Policies: A Case Study of Cluster Policy in the West Midlands in the UK. European Planning Studies, 22(9), 1940-1959. http://dx.doi.org/10.1080/09654313.2013.812066

Herstad, S., Aslesen, H., \& Erbersberger, B. (2014). On industrial knowledge bases, commercial opportunities and global innovation network linkages. Research Policy, 43(3), 495-504. http://dx.doi.org/10.1016/j.respol.2013.08.003

Hirschman, E. C. (1980). Innovativeness, Novelty Seeking, and Consumer Creativity. Journal of Consumer Research, 7(3), 283-295. http://dx.doi.org/10.1086/208816

Ho, J. C., \& Lee, Ch. S. (2015). A Typology of technological change: Technological paradigm theory with validation and generalization from case studies. Technological Forecasting and Social Change, 97, 128-139. http://dx.doi.org/10. 1016/j.techfore.2014.05.015

Hori, T., Ikefuji, M., \& Mino, K. (2015) Conformism and Structural Change. International Economic Review, 56(3), 939961. http://dx.doi.org/10.1111/iere. 12127

Huggins, R., Izushi, H., Prokop, D., \& Thompson, P. (2014). Regional Evolution and Waves of Growth: a Knowledge-based Perspective. Expert Systems with Applications, 41(12), 5573-5586. http://dx.doi.org/10.1016/j. eswa.2014.02.008

Jucu, I. S. (2015). Romanian Post-socialist Industrial Restructuring at the Local Scale: Evidence of Simultaneous Processes of De-/Reindustrialization in the Lugoj Municipality of Romania. Journal of Balkan and Near Eastern Studies, 17(4), 408-426. http://dx.doi.org/10.1080/19448953.2015.1063302

Keating, M. (2001). Rethinking the region - Culture, institutions and economic development in Catalonia and Galicia. European Urban and Regional Studies, 8(3), 217-234. http://dx.doi.org/10.1177/096977640100800304

Kellerman, A. (1985). The evolution of services economies: a geographical perspective. The Professional Geographer, 37(2), 133-143. http://dx.doi.org/10.1111/j.0033-0124.1985.00133.x

Kenessey, Z. (1987). The primary, secondary, tertiary and quaternary sectors of the economy. Review of Income and Wealth, 33(4), 359-385. http://dx.doi.org/10.1111/j.1475-4991.1987.tb00680.x

Kraft, J., \& Kraftova, I. (2012). Innovation - Globalization - Growth (Selected Relations). Inzinerine EkonomikaEngineering Economics, 23(4), 395-405. http://dx.doi.org/10.5755/j01.ee.23.4.2568

Kraftova, I., Prasilova, P., \& Mateja, Z. (2011). High-tech Sector and the European Lagging in the Globalized Economy. In A. Kocourek (Ed.) Proceedings of the 10th International Conference Liberec Economic Forum 2011, (pp. 286-295). Liberec: TUL.

Kraftova, I., Mateja, Z., \& Zdrazil, P. (2013). Innovation Industry Drivers. In A. Kocourek (Ed.) Proceedings of the 11th International Conference Liberec Economic Forum 2013 (pp. 334-342). Liberec: TUL.

Krugman, P. (1979). A Model of Innovation, Technology Transfer, and the World Distribution of Income. Journal of Political Economy, 87(2), 253-266. http://dx.doi.org/10.1086/260755

Kuznets, S. (1971). Economic Growth of Nations: Total Output and Production Structure. Cambridge: Harvard University Press. http://dx.doi.org/10.4159/harvard.9780674493490

Kuznets, S. (1973). Modern, Economic Growth. New Haven: Yale University Press.

Leydesdorff, L., \& Fritsch, M. (2006). Measuring the knowledge base of regional innovation systems in Germany in terms of a Triple Helix dynamics. Research Policy, 35(10), 1538-1553. http://dx.doi.org/10.1016/j.respol.2006.09.027

Maddison, A. (1980). Economic Growth and Structural Change in Advanced Countries. In I. Levenson, J. Wheeler (Ed.) Western Economies in Transition: Structural Change and Adjustment Policies in Industrial Countries (pp. 41-60). Boulder: Westview press.

Malecki, E. (2010). Global knowledge and creativity: new challenges for firms and regions. Regional Studies, 44(8), 10331052. http://dx.doi.org/10.1080/00343400903108676

Malmberg, A., \& Maskell P. (2002). The elusive concept of localization economies: towards a knowledge-based theory of spatial clustering. Environment and Planning A, 34(3), 429-449. http://dx.doi.org/10.1068/a3457

Maskell, P., \& Malmberg, A. (1999). The competitiveness of firms and regions - 'Ubiquitification' and the importance of localized learning. European Urban and Regional Studies, 6(1), 9-25. http://dx.doi.org/10.1177/09697 7649900600102 
McCann, P., \& Ortega-Argiles, R. (2015). Smart Specialization, Regional Growth and Applications to European Union Cohesion Policy. Regional Studies, 49(8), 1291-1302. http://dx.doi.org/10.1080/00343404.2013.799769

Miozzo, M., \& Miles, I. (2002). Internationalization, Technology and Services.Cheltenham: Edward Elgar.

Muller, E., Jappe, A., Heraud, J., \& Zenker, A. (2006). A regional typology of innovation capacities in new member states \& candidate countries. Working Papers Firms and Region, No. R1. Frauenhofer ISI Karlsruhe. Available from internet: http://publica.fraunhofer.de/eprints/urn_nbn_de_0011-n-357899.pdf

Naisbitt, J. (1994). Global Paradox. The Bigger the World Economy, the More Powerful Its Smallest Players. New York: Avon Books.

North, D. (1994). Economic Performance Through Time. The American Economic Review, 84(3), 359-368.

OECD. (1995). The measurement of scientific and technological activities: "Canberra manual". Paris: OECD.

Peretto, P.F. (2015). From Smith to Schumpeter: A theory of take-off and convergence to sustained growth. European Economic Review, 78, 1-26. http://dx.doi.org/10.1016/j.euroecorev.2015.05.001

Perez, C. (1983). Structural Change and Assimilation of New Technologies in the Economic and Social Systems. Futures, 15 (4), 357-375. http://dx.doi.org/10.1016/0016-3287(83)90050-2

Rodrik, D. (2011). The Globalization Paradox: Democracy and the Future of the World Economy. New York: W. W. Norton.

Saboniene, A. (2010). The evaluation of the potential of Lithuanian manufacturing industry structure on the basis of CI index. Inzinerine Ekonomika-Engineering Economics, 21(4), 399-407.

Shapiro, C., \& Varian, H. (1999). Information Rules: A Strategic Guide to the Network Economy. Boston: Harvard Business School Press.

Snieska, V., \& Bruneckiene, J. (2009). Measurement of Lithuanian Regions by Regional Competitiveness Index. Inzinerine Ekonomika-Engineering Economics, 61(1), 45-56.

Steinmetz, A. (2015). Competition, innovation, and the effect of R\&D knowledge. Journal of Economics, 115(3), $199-230$. http://dx.doi.org/10.1007/s00712-014-0415-3

Stiglitz, J.E. (2015). Leaders and followers: Perspectives on the Nordic model and the economics of innovation. Journal of Public Economics, 127 (SI), 3-16.

Tavassoli, S., \& Carbonara, N. (2014). The role of knowledge variety and intensity for regional innovation. Small Business Economics, 43(2), 493-509. http://dx.doi.org/10.1007/s11187-014-9547-7

Teece, D. (2007). Explicating dynamic capabilities: The nature and microfoundations of (sustainable) enterprise performance. Strategic Management Journal, 28(13), 1319-1350. http://dx.doi.org/10.1002/smj.640

Tödtling, F., Asheim, B., \& Boschma, R. (2012). Knowledge sourcing, innovation and constructing advantage in regions of Europe. European Urban and Regional Studies, 20(2), 161-169. http://dx.doi.org/10.1177/0969776412457173

Tödtling, F., Grillitsch, M., \& Hoglinger, C. (2012). Knowledge Sourcing and Innovation in Austrian ICT companies - How Does Geography Matter? Industry and Innovation, 19(4), 327-348. http://dx.doi.org/10.1080/136 62716.2012.694678

Uppenberg, C., \& Strauss, H. (2010). Innovation and productivity growth in the EU services sector. Luxembourg: European Investment Bank.

Valenta, F. (2001). Innovation in the managerial practice [Inovace v manazerske praxi]. Praha: Velryba.

Van Ark, B., O’Mahoney, M., \& Timmer, M. (2008). The Productivity Gap between Europe and the United States: Trends and Causes. Journal of Economic Perspectives, 22(1), 25-44. http://dx.doi.org/10.1257/jep.22.1.25

The article has been reviewed.

Received in November, 2015; accepted in June, 2016. 